\title{
PLANTS USED IN SOME COMMON DISEASES FOR CHILD CARE
}

\author{
1L.K. Dhumal*, 2 P.R. Barve and ${ }^{3}$ C.S. Arsule \\ ${ }^{1}$ New Arts, Commerce and Science College Ahmednagar, 414001, M.S.India. \\ ${ }^{2}$ Mahatma Gandhi Mission Dental College and Hospital, New Mumbai, Panvel. \\ ${ }^{3}$ New Arts, Commerce and Science College Ahmednagar, 414001, M.S. India. \\ *Corresponding Author:- lata_dhumal@rediffmail.com
}

\begin{abstract}
:
Children are the most susceptible to various types of viral diseases and infectious due to low immune system. There are many important diseases which are common in children worldwide such as gastrointestinal, respiratory, urinary, kidney disorders, liver, ear nose throat disease (ENT), eye infection, and dental anomalies. Immune system diseases as a result of nutrition deficiency are the key element for child diseases. India is a land of rich biodiversity and indigenous knowledge, particularly traditional ethnomedical practices. It is reported that the folk medicine system of India uses about 5000 different plant species with about 25,000 formulations as medicines for various ailments whereas the tribal healers use about 8000 wild plants with nearly 1,75,000 preparations. Various medicinal plants have been used by people for child care. Most of the commonly used plant part is root, stem. Leaf, fruit, seed etc. There is a need to conduct clinical trials to support traditional claims and to analyse cellular and molecular mechanisms involved. Leaves and fruits are most used parts, herbs are most used life form, decoction method were used for administration, and oral ingestion was the main used route of application. Most of the species in the present study were used to cure gastrointestinal.
\end{abstract}

Key words: - Viral, Immune, Ethnomedical, Decoction, Traditional.

\section{INTRODUCTION:}

Throughout the ages, humans have relied on nature for their basic needs, for the production of food, shelter, clothing, transportation, fertilizers, flavours and fragrances, and medicines (Cragg and Newman, 2005). Plants have formed the basis of sophisticated traditional medicine systems that have been inexistence for thousands of years and continue to provide mankind with new remedies. Although medicinal plant therapy is based on the empirical findings of hundreds and probably thousands of years of use. The first records, written on clay tablets in cuneiform, are from Mesopotamia and date from about 2600 BC (Heinrich etal. 2004). Among the substances that were used are oils of Cedrus species (cedar) and Cupressus sempervirens (cypress),
Glycyrrhiza glabra (licorice), Commiphora species (myrrh) and Papaver somniferum (poppy juice), all of which are still in use today for the treatment of ailments ranging from coughs and colds to parasitic infections and inflammation. In ancient Egypt, bishop's weed (Ammi majus) was reported to be used to treat vitiligo, a skin condition characterized by a loss of pigmentation (Stanisze wska, et al., 2003; Beissert and Schwarz, 2002). More recently, a drug (methoxypsoralen) has been produced from this plant to treat psoriasis and other skin disorders, as well as T-cell lymphoma (Beissert and Schwarz, 2002).

The interest in nature as a source of potential chemotherapeutic agent continues. Natural and their derivatives represent more than $50 \%$ of all the drugs products in clinical 
use in the world today. Higher plants contribute no less than $25 \%$ of the total (Farnsworth et al., 1985; Cragg and Newman, 2005). In the last 40 years, many potent drugs have been derived from flowering plants.

The purpose of this review is to present few lesser known traditional Indian medicinal plants, their bioactive phytochemical, part of the plant used in various children diseases.

In present study the survey $\&$ documentation of 15 plants useful in child health care were studied.

Enumeration of plants includes botanical name, family, local names and uses with detailed formulation mode of use doses. These plant species are related to the various paediatric problems. These plants have been utilized as home remedies. Some plants are also in the product like "Balghuti".

\section{MATERIALS AND METHODS:}

\section{1) Botanical Name-Acacia nilotica L.Corr.}

Common name-Babhul

Family-Mimosaceae

Plant part use-Gum, Leaf.

Uses-

1) $5 \mathrm{gm}$ gum is dissolved in 1 cup of water and is given in the morning in empty stomach for 3 days to cure dysentery.

2) About $2 \mathrm{ml}$ leaf bud past mixed with a pinch of dried rhizome powder of Zingiber officinale.It is given with water twice a day for 2-3 day to cure diarrhoea.

3) Leaf paste is applied on affected area to reduce the swelling $\&$ pain.

\section{2) Botanical Name-Acorus calamus Linn.}

Common name-Vekhand, Bajho.

Family-Aracaceae.

Plant part use-Rhizome.
1) A paste prepared from fresh and dried rhizome is applied externally on skin disease and on the forehead during fever.

2) Rhizome paste (1-2gm) with water is given thrice a day for 2-3 days to cureDiarrhoea.

3) $5 \mathrm{gm}$ rhizome paste is applied twice a day up to 7 days onChicken pox.

4) A pinch of rhizome paste is applied in side mouth, twice a day for 1-2 days or till curemouth ulcer.

5) $5 \mathrm{ml}$ decoction of rhizome is given twice a day till curecough and cold.

\section{3) Botanical name-Aegle marmelos (L.) Corr.}

Common name-Bel.

Family-Rutaceae.

Plant part use-Leaf, Fruit.

Uses-

1) Juice extracted from 2-3-fresh leaves with a pinch of salt is given on empty stomach for 2-3 days to cure fever.

2) Powder of dried green fruit pulp with water is given a for 3 days to treat dysentery and diarrhoea.

3) Ripen fruits pulp is mixed with water and juice is prepared and given for 7-8 daysConstipation.

4) Botanical name- Bacopa monnieri (L.) Penn.

Common name-Nirbramhi.

Family- Scrophulariaceae.

Plant part use-Leaves.

1) $5-10 \mathrm{ml}$ plant juice with $1 / 2$ cup of cow's milk given once a day for 20-25 days as abrain tonic.

2) $10 \mathrm{ml}$ juice of whole plant mixed with 25 $\mathrm{ml}$ mustard oil \& $5 \mathrm{gm}$ of black mung flour warmed \&gently massaged over 
chest to get relief from pain due to congestion.

3) $5 \mathrm{ml}$ Plant juice with $1 / 2$ cup of cow's milk given twice a day for 2-3 days to cure cold.

\section{5) Botanical name- Ferula asafoetida L.}

Common name- Hing.

Family- Apiaceae.

Plant part use- Seeds.

1. Useful in dyspnoea of children.

2. It produces remarkable effects in the advanced stage

of pneumonia\&Bronchia's of children.

3. It is stimulant respiratory \& nervous system \&very effective.

4. The Ferula is used as maintain body temperature.

\section{6) Botanical name- Trachyspermum ammni}

\section{(L.)}

Common name- Onwa, Ajwain.

Family- Apiaceae.

Plant part used- Seeds.

Uses-

1. Administrative three drops of oil extracted from seeds treats gastrointestinal disorder.

2. Ajwain-kaphool treats for stomach ache.

3. Apply paste of ajwain on stomach.

4. Heated $1 / 2$ teaspoon seeds in $30 \mathrm{ml}$ milk filter \& used as ear drop to reduce congestion \& relief pain.

7) Botanical name- Rosa setigera Michx.

Common name-Gulab.

Family- Rosaceae.

Plant part use-Flower.

Uses-

1. A syrup made from the flower is given to children for vitamin-c.
2. Syrup prepared from flower is used to treat ellipse $\&$ insomnia.

8) Botanical name- Ruta graveolens.L.

Common name- Satap.

Family- Rutaceae.

Plant part use- Leaves.

Uses-

1. The dried leaves used as a fumigator for children suffering fromcatarrh with catarrh powder \& combination with aromatics they are given in dyspepsia. .

2. In some parts of India, the juice is given to children as a remedy for worms.

3. The leaf juice is given to infants \& children with conclusion $\&$ fits.

4. It is used in chronic diseases or bronchitis.

5. The bruised herb is placed in hollow teeth $\&$ the ears to relive toothache $\&$ earache respectively.

9) Botanical name- Gardenia resinifera Roth. Common name-Dikamali.

Family- Rubiaceae.

Plant part use- Root.

Uses

1. The roots preparation of Gardenia is used as a remedy for ingestion of children.

2. Dikamali powder is safe to use for babies during teething.

10) Botanical name- Prunus amygadalus L.Batsh.

Common name- Badam.

Family- Rosaceae.

Plant part use- Fruit.

Uses

1. The powder of Badam is mixed with milk to cure the problem of weakness.

2. The nutrients in almonds are essential to baby's brain development. 
3. The presence of a right amount of phosphorus in almonds enhances baby's bones and teeth as they grow.

11) Botanical name- Foeniculum vulgare L.

Common name- Badishep.

Family- Apiaceae.

Plant part use- Seeds.

Uses

1. Syrup prepared from fennel is use for chronic cough.

2. It cures intestinal trouble when applied to the abdomen of children.

3. The fennel ark is used for stomach ache \&indigestion.

4. Protection from different microbes.

5. When infants suffer from constant respiratory issues and diseases such as bronchitis, asthma and cough.

6. Relief from constipation.

12) Botanical name- Helicteres isora $\mathrm{L}$.

Common name- Murud sheng.

Family- Sterculiaceae.

Plant part use- Root, stem bark.

Uses

1. $5 \mathrm{ml}$ Decoction of bark and pods once a day is effective or diarrhoea.

2. $3 \mathrm{~m}$, bark decoction twice a day is for asthma and cough.

3. Useful in the gripping of bowels and flatulence of children.

\section{2) Botanical name- Vitis vinifera $L$.}

Common name-Draksh.

Family- Vitaceae.

Plant part use-Fruit.

Uses

1) Grapes are useful in case of small pox and insomnia.

2) The juice is used as the body temperature maintain.

\section{4) Botanical name- Myristica fragrens $L$.}

Common name- Jaiphal.

Family-Myristicaceae

Plant part use- Seed, seed coat, oil.

Uses

1) Giving jaiphal to baby may prove to be beneficial for his tummy.

2) Inducing better sleep in babies because it is a natural sedative.

3) It helps in building up a better appetite.

4) It is anti- carminative and antispasmodic among remedies for children.

\section{5) Botanical name- Embelia ribes $\mathbf{L}$.}

Common name- Ambati, Vavding.

Family- Myrsinaceae

Plant part use- Berry.

Uses

1) Powder mixed with honey or sugar is given on empty stomach to expel tape worms.

2) The plant is widely used as antihelminthic, anti-carminative, antibacterial, anti-inflammatory, antidiuretic and anti-astringent.

\section{CONCLUSION:}

Today according to the World Health Organization (WHO), as many as $80 \%$ of the world's people depend on traditional medicine for their primary health care needs. There are considerable economic benefits in the development of indigenous medicines and in the use of medicinal plants for the treatment of various diseases. Ethnobotany is not new to India because of its rich ethnic diversity.

In the developed countries, 25 per cent of the medical drugs are based on plants and their derivatives. The plant parts used for treatment of childillness in this review was found to be root 
followed by leaves and itwas unlike with other ethno-botanical studies which were leaf was thedominant plant part used and the common rout of administration was through orals.

\section{ACKNOWLEDGEMENTS:}

The authors are thankful to Principle of New Arts, Commerce and Science College, Ahmednagar, and Head of Department of Botany, New Arts, Commerce and Science College Ahmednagar for providing necessary facilities for this work.

\section{REFERENCES:}

Alviano, D. S., \& Alviano, C. S. (2009). Plant extracts: search for new alternatives to treat microbial diseases. Current Pharmaceutical Biotechnology, 10(1), 106-121.

Charantimath, S., \& Oswal, R. (2013). Herbal therapy in dentistry: a review. Innovative Journal of Medical and Health Science, $1(1)$.

Pushpangadan, P., \& George, V. (2010). Ethnomedical practices of rural and tribal populations of India with special reference to the mother and child care. Indian Journal of Traditional Knowledge, 9(1), 9-17.
Palombo, E. A. (2011). Traditional medicinal plant extracts and natural products with activity against oral bacteria: potential application in the prevention and treatment of oral diseases. EvidenceBased Complementary and Alternative Medicine, 2011.

Kirtikar, K. R. (1935). Indian Medicinal Plants, Vol. 2. Lalit Mohan Basu, Allahabad, India. P-1527-28.

Banso, A. (2009). Phytochemical and antibacterial investigation of bark extracts of Acacia nilotica. Journal of Medicinal Plants Research, 3(2), 082-085

Kalaivani, T. (2013). Antimicrobial Property of Potent Medicinal Plant Acacia Nilotica (L.) Wild.Ex. Delile Subsp. Indica (Benth.) Brenan. International $J$. Pharmacy and Pharmaceutical. Sciences, 5(2), 467-470.

Khan, R., Zakir, M., Afaq, S. H., Latif, A., \& Khan, A. U. (2010). Activity of solvent extracts of Prosopis spicigera, Zingiber officinale and Trachyspermum ammi against multidrug resistant bacterial and fungal strains. The Journal of Infection in Developing Countries, 4(05), 292-300. 